\title{
The effects of sprinkler+fan, fish meal or dietary fat on milk yield and milk composition of dairy cows in mid lactation during summer ${ }^{*}$
}

\author{
U. Serbester ${ }^{1}$, M. Görgülü̈ ${ }^{1,4}$, H.R. Kutlu ${ }^{1}$, S. Yurtseven ${ }^{1}$, A. Arieli ${ }^{2}$ and \\ Z.M. Kowalski ${ }^{3}$ \\ ${ }^{1}$ University of Cukurova, Faculty of Agriculture, Department of Animal Science \\ 01330 Adana, Turkey \\ ${ }^{2}$ Department of Animal Science, Faculty of Agricultural, \\ Food and Environmental Quality Sciences, The Hebrew University of Jerusalem, Rehovot 76-100, Israel \\ ${ }^{3}$ The Agricultural University of Cracow, Department of Animal Nutrition \\ Al. Mickiewicza 24-28, 30-059 Kraków, Poland
}

(Received 19 November 2004; revised version 25 July 2005; accepted 17 October 2005)

\section{ABSTRACT}

Two studies were conducted to evaluate 1. the effectiveness of sprinkler+fan (SF) and fish meal (FM) and 2. SF and protected fat (PF) in alleviation of heat stress in dairy cows in mid lactation. The studies were carried out in $2 \times 2$ factorial arrangement, in a $4 \times 4$ Latin square design on four multiparous lactating dairy cows. The treatments in the first trial were 1 . no SF and no FM, 2. no SF and $3.67 \% \mathrm{FM}$ in the diet (on DM basis), 3. SF and no FM and 4. SF and 3.67\% FM. The treatments in the second trial were 1. no SF and no PF, 2. no SF and 2.54\% PF in the diet (on DM basis), 3. $\mathrm{SF}$ and no PF and 4. SF and 2.54\% PF. Cows were fed with isoenergetic and isonitrogenic TMR, containing 2.52 Mcal ME/kg DM and $180 \mathrm{~g} \mathrm{CP} / \mathrm{kg}$ DM. The cows received mild heat stress for $9 \mathrm{~h}$ (from 07.00 to 10.00 and from 17.00 to 23.00 ) and moderate heat stress for $7 \mathrm{~h}$ (from 10.00 to 17.00) daily for the entire experimental period.

$\mathrm{SF}$ decreased $(\mathrm{P}<0.05)$ rectal and skin temperature and respiration rate. SF improved milk yield for $2.21 \mathrm{~kg}$ in the first trial $\left(\mathrm{P}<0.07,19.24 \mathrm{vs} 21.45 \mathrm{~kg} \mathrm{~d}^{-1}\right)$ and $1.22 \mathrm{~kg}$ in the second one $(\mathrm{P}=0.15$, 19.47 vs $\left.20.69 \mathrm{~kg} \mathrm{~d}^{-1}\right)$. FM had no effect on milk yield of neither cooled nor no cooled cows, but tended to increase $(\mathrm{P}=0.12)$ milk protein, independently from $\mathrm{SF}$ application. Additionally, $\mathrm{PF}$ increased FCM and fat yield $(\mathrm{P}<0.05)$ and tended to increase $(\mathrm{P}=0.07)$ milk fat content independently from SF application.

\footnotetext{
$\bar{*}$ Supported by TR State Planning Organization (DPT), Cukurova Agricultural Research Institute, Cukurova University Research Fund, NOVARTIS-Turkey and EKOL Gida Tarim ve Hayvancilik A.S.-Turkey

${ }^{4}$ Corresponding author: e-mail: gorgulu@cu.edu.tr
} 
The results of both studies suggest that applying sprinklers plus fan can improve milk yield better than nutritional manipulation using either FM or PF. The results also suggested that PF could be more beneficial than FM under heat stress condition when the dietary protein level is high.

KEY WORDS: heat stress, protected fat, fish meal, sprinkler+fan, cooling

\section{INTRODUCTION}

High temperature and humidity during summer months in Cukurova Region, Southern Turkey, owing a subtropical climatic condition, may reduce milk production of dairy cows. Evaporative cooling is one of the most effective ways for reducing heat stress in livestock. This process is accomplished by directly wetting skin surface and fur layer followed by convective cooling by means of fan (Gebremedhin and $\mathrm{Wu}, 2002$ ). The effectiveness of evaporative cooling also depends on air humidity and airy velocity. It has been reported that providing sprinkler in the feeding line, holding pen and exit lane (Armstrong, 1993) increased milk yield in lactating dairy cows.

In order to alleviate heat stress by decreasing heat increment in the body, dietary manipulation could also be employed by using energy-dense diets and/or the nutrients which have less metabolic heat production per unit of energy ingested by the animal (White et al., 1992). Feeding diets supplemented with fat under normal (Madison-Anderson et al., 1997) and heat stress condition (Chan et al., 1997) or rumen undegradable high quality protein sources under normal (Overton et al., 1998) and heat stress conditions (Higginbotham et al., 1989) seemed to have potential to alleviate the negative influences of heat stress and increased milk yield.

The present literature has limited information on the effect of protected fat or fish meal and sprinkler+fan interactions in heat stressed dairy cows (Chan et al., 1997) in mid lactation. Heat stress generally decreases feed intake and evaporative cooling alleviates reduction in feed intake. Some interactions are, therefore, expected when animal environment and nutritional status are improved. Hence, two studies were carried out to determine the effect of sprinkler+fan and dietary fat, and sprinkler+fan and fish meal and/or their associative effects on milk yield and milk composition in mid lactation of dairy cows.

\section{MATERIAL AND METHODS}

Two studies were conducted to determine whether 1. sprinkler+fan (SF) plus feeding with fish meal (FM) and 2. sprinkler+fan (SF) plus feeding with protected fat (Ca salt of long chain fatty acid, RTA-LAC trade mark (Novakim, Kocaeli, Turkey) containing, \%: dry matter, 95; fatty acids, 84; and ash 11 would 
have potentials in alleviation of heat stress in dairy cows in mid lactation. The studies were carried out simultaneously at the Experimental Farm of the Faculty of Agriculture, the University of Cukurova, Adana-Southern Turkey. Minimum, maximum and average values for temperature, relative humidity, and temperature humidity index (THI) during experiment were determined as $21.5,32.8,26.6^{\circ} \mathrm{C}$, and $39.7,82.5,61.7 \%$, and $68.9,80.6$ and 74.4 , respectively.

\section{Animals, feeding and maintenance}

Eight multiparous Holstein dairy cows, averaging $500 \pm 22.7 \mathrm{~kg}$ liveweight, $150 \pm 9.8 \mathrm{DIM}$, yielding $23.0 \pm 1.1 \mathrm{~kg} \mathrm{~d}^{-1}$ milk, were assigned to the studies. After a week preliminary period for the adaptation to the experimental unit, each cow

TABLE 1

Ingredients and chemical compositions of the diets, $\mathrm{g} / \mathrm{kg}, \mathrm{DM}$ basis

\begin{tabular}{lrrr}
\hline Indices & $\begin{array}{c}\text { Control TMR } \\
\text { no fish meal, no fat }\end{array}$ & $\begin{array}{c}\text { TMR with } \\
\text { fish meal }\end{array}$ & $\begin{array}{c}\text { TMR with } \\
\text { protected fat }\end{array}$ \\
\hline Ingredients & & & \\
maize & 11.13 & 11.13 & 11.16 \\
barley & 27.19 & 24.38 & 6.82 \\
wheat bran & 0.87 & 7.41 & 20.79 \\
cottonseed cake (34\%) & 9.02 & 9.02 & 9.05 \\
soyabean meal (44\%) & 9.71 & 2.84 & 8.22 \\
lucerne hay & 40.01 & 40.02 & 40.14 \\
fish meal (66\%) & - & 3.67 & - \\
protected fat ${ }^{1}$ & - & - & 2.54 \\
vitamin mineral mixture & 0.06 & 0.06 & 0.06 \\
limestone & 1.69 & 1.15 & 0.90 \\
salt & 0.32 & 0.32 & 0.32 \\
Chemical composition,\% & & & \\
dry matter & & & 89.98 \\
crude protein & 90.27 & 90.26 & 18.27 \\
ether extract & 18.06 & 18.03 & 4.97 \\
ADF & 2.43 & 2.71 & 19.88 \\
NDF & 18.36 & 18.49 & 32.03 \\
crude ash & 27.95 & 29.13 & 7.63 \\
Ca & 6.66 & 7.12 & 1.33 \\
$\mathrm{P}^{4}$ & 1.31 & 1.24 & 0.58 \\
ME, Mcal/kg & 0.43 & 0.55 & 2.52 \\
RUP, \%CP & 2.52 & 2.52 & 36.04 \\
\hline
\end{tabular}

${ }^{1}$ fish meal (\% $\left.66 \mathrm{CP}\right)$ was imported from Peru

${ }^{2}$ protected fat was RTA-LAC trade mark containing $95 \%$ dry matter, $84 \%$ fatty acids, and $11 \%$ ash $(9 \% \mathrm{Ca})$

${ }^{3}$ each $\mathrm{kg}$ vitamin-mineral mixture provides; IU: 8.000 .000 vit. A, vit. D3 1.000.000; mg: vit. E 30.000, Mn 50.000, Zn 50.000, Fe 50.000, Cu 10.000, Co 150, I 800 and Se 150

${ }^{4}$ RUP - rumen undegradable protein

${ }^{5}$ values were calculated from NRC (2001) 
was fed ad libitum with its own dietary treatments. Daily feed refusals were given to the animal on following day, and on the final day of data collection period cows were allowed to consume all feed offered. The TMRs, each containing $60 \%$ concentrate and $40 \%$ lucerne hay chopped in $1.5-2 \mathrm{~cm}$ length, were formulated as isocaloric and isonitrogenic (Table 1). Fresh water was available freely during the entire experimental period.

The cows were housed in free-stall individual paddocks, sized $2.5 \mathrm{~m} \times 3 \mathrm{~m}$ concrete feeding alley and $2.5 \mathrm{~m} \times 3 \mathrm{~m}$ compressed soil area for resting. Feeding alley was covered with roof for shade. Two parallel pipelines with sprinkler were mounted $1 \mathrm{~m}$ above from cows in feeding line and two fans having $50 \mathrm{~cm}$ diameter with the $30^{\circ}$ slope were connected $2.5 \mathrm{~m}$ far from the nearest paddock above the feeding line. The sprinklers in the pipeline were spaced $40 \mathrm{~cm}$ far from each other above the cows and each paddock had total 6 sprinkler heads supplying $3 \mathrm{~L}$ water/ min. Sprinklers and fans were switched on by an electricity timer from 10.00 to 17.00 for $15 \mathrm{~min}$ every h and fans were also turned on 22.00 to 05.00 for $15 \mathrm{~min}$ per $\mathrm{h}$ to avoid high humidity at night.

\section{Measurements and analytical procedures}

Dry matter, crude protein, ether extract and crude ash of experimental diets were determined according to the AOAC procedures (1998). NDF and ADF contents of the diets were determined in ANKOM Fiber Analyser using Van Soest et al. procedure (1991). Metabolizable energy, rumen undegradable protein, $\mathrm{Ca}$ and $\mathrm{P}$ content of the diets were calculated based on the table values published by NRC (2001).

The cows were milked at 06.00 and $16.00 \mathrm{~h}$ daily using a central computerized milking system. A representative milk sample from each cow was collected from morning milk to analyse milk composition. Milk fat was determined by Gerber method. Milk samples were also analysed for dry matter, ash, milk protein, NPN, casein nitrogen according to AOAC (1998). Protein nitrogen, whey nitrogen, protein nitrogen to total nitrogen ratio, casein nitrogen to total nitrogen ratio, were calculated. Lactose was calculated by subtracting fat plus protein from milk organic matter. Milk yield and feed intake were determined daily.

Rectal temperature was recorded using a digital thermometer by inserting 6-8 $\mathrm{cm}$ into the rectum. Skin temperatures were measured on right fossa paralumbalis using a portable infrared thermometer (Raytek MT4, Minitemp) with $10 \mathrm{~cm}$ away from the skin. Respiration rate was determined visually by counting number of breaths per min. Heart rate below left elbow was also recorded by a stethoscope. Body temperature, heart and respiration rates were taken at $2 \mathrm{~h}$ intervals from 11.00 to 15.00 during the $10^{\text {th }}$ day of adaptation, and on $3^{\text {rd }}$ and $5^{\text {th }}$ days of the data 
collection periods by trained person. Ambient temperature and relative humidity were recorded $24 \mathrm{~h}$ per day with $1 \mathrm{~h}$ interval by a data logger (Hobo H8 Family, Onset computer corporation's Boxcar) during the studies. Temperature-humidity index was calculated by the equation:

THI $=0.8 \times$ Dry-Bulb Temp. ${ }^{\circ} \mathrm{C}+($ Relative Humidity $/ 100) \times($ Dry-Bulb Temp. ${ }^{\circ} \mathrm{C}-14.3$ ) +46.3 (Lefcourt and Schmidtmann, 1989).

\section{Experimental design and statistics}

Each study was carried out in $2 \times 2$ factorial arrangements in a $4 \times 4$ Latin square design, having 21 days ( 14 days for adaptation, 7 days for data collection) for each period. The treatments in the first trial were 1. no SF and no FM, 2. no SF and 3.67\% FM in the diet (on DM basis), 3. SF and no FM and 4. SF and $3.67 \% \mathrm{FM}$. The treatments in the second trial were 1. no SF and no PF, 2. no SF and $2.54 \% \mathrm{PF}$ in the diet (on DM basis), 3. SF and no PF and 4. SF and $2.54 \% \mathrm{PF}$.

Data obtained in each trial were analysed by GLM procedure of SAS (1985) using following model:

where:

$$
\mathrm{Y}_{\mathrm{ijklm}}=\mathrm{M}+\mathrm{C}_{\mathrm{i}}+\mathrm{P}_{\mathrm{j}}+\mathrm{SF}_{\mathrm{k}}+\mathrm{D}_{1}+\mathrm{SFD}_{\mathrm{kl}}+\mathrm{E}_{\mathrm{ijklm}}
$$

$\mathrm{M}=$ overall mean

$\mathrm{C}_{\mathrm{i}} \quad=$ cow effect

$\mathrm{P}_{j} \quad=$ period effect

$\mathrm{SF}_{\mathrm{k}}=$ sprinkler+fan effect

$\mathrm{D}_{1} \quad=$ fish meal or protected fat effect

$\mathrm{SFD}_{\mathrm{kl}}=$ sprinkler + fan and fish meal or protected fat interaction effect

$\mathrm{E}_{\mathrm{ijklm}}=$ random error.

Duncan's Multiple Range Test was performed for the separation of the means.

\section{RESULTS}

Because of the climatic condition under which the both trials were performed, it was observed that all cows were suffered mild heat stress for $9 \mathrm{~h}$ (from 07.00 to 10.00 and from 17.00 to 23.00 ) and moderate heat stress for $7 \mathrm{~h}$ (from 10.00 to 17.00) daily. The cows having sprinkler and fan system over the feeding line tended to have a higher milk yield $\left(2.21 \mathrm{~kg} \mathrm{~d}^{-1}\right.$ more milk in the FM study; $\mathrm{P}=0.07), 19.24$ vs $21.45 \mathrm{~kg} \mathrm{~d}^{-1}$ and $1.22 \mathrm{~kg} \mathrm{~d}^{-1}$ in the PF study, 19.47 vs 20.69 $\mathrm{kg} \mathrm{d}^{-1} ; \mathrm{P}=0.17$ ) than the non-cooled cows (Tables 2 and 4). The cooled cows had also higher milk protein yield $(\mathrm{P}<0.05)$ in the FM meal study and tended to have 
higher milk protein yield ( $\mathrm{P}=0.12)$ in the $\mathrm{PF}$ study due to slightly higher milk yield than the non-cooled cows. SF application in the both studies decreased $(\mathrm{P}<0.01)$ rectal temperature (except at 11.30 in the first study), skin temperature and respiration rate (Tables 3 and 5), however, DMI, CPI, MEI were not affected by $\mathrm{SF}(\mathrm{P}>0.05)$.

FM had no effect on milk yield of neither cooled nor non-cooled cows, but tended to increase $(\mathrm{P}=0.12)$ milk protein, independently from $\mathrm{SF}$ application. FM did not affect $(\mathrm{P}>0.05$; Table 2$)$ milk yield, milk composition and nitrogen

TABLE 2

The effects of sprinkler+fan (SF) and fish meal (FM) on milk yield, DM and nutrient intakes and milk composition

\begin{tabular}{|c|c|c|c|c|c|c|c|c|}
\hline \multirow{2}{*}{$\begin{array}{l}\text { Sprinkler+Fan } \\
\text { Fish meal }\end{array}$} & \multicolumn{2}{|c|}{ No } & \multicolumn{2}{|c|}{ Yes } & \multirow{2}{*}{ SE } & \multicolumn{3}{|c|}{ Effects $(\mathrm{P}<)$} \\
\hline & No & Yes & No & Yes & & SF & FM & $\mathrm{SF} \times \mathrm{FM}$ \\
\hline Milk yield, kg/day & 18.98 & 19.50 & 21.79 & 21.10 & 0.98 & 0.07 & 0.94 & 0.56 \\
\hline FCM, kg/day & 16.90 & 16.82 & 18.80 & 17.89 & 0.86 & 0.13 & 0.58 & 0.65 \\
\hline DMI, kg/day & 19.15 & 19.27 & 19.74 & 20.66 & 0.69 & 0.20 & 0.48 & 0.59 \\
\hline RUP intake, $\mathrm{kg} /$ day & $1.21^{\mathrm{b}}$ & $1.32^{\mathrm{ab}}$ & $1.26^{\mathrm{ab}}$ & $1.43^{\mathrm{a}}$ & 0.06 & 0.20 & 0.06 & 0.61 \\
\hline ME intake, Mcal/day & 48.25 & 48.57 & 49.75 & 51.95 & 1.75 & 0.21 & 0.50 & 0.61 \\
\hline $\mathrm{CP}$ intake, $\mathrm{kg}$ /day & 3.46 & 3.47 & 3.57 & 3.72 & 0.13 & 0.21 & 0.54 & 0.61 \\
\hline NDF intake, $\mathrm{kg}$ /day & 5.35 & 5.62 & 5.52 & 6.01 & 0.20 & 0.20 & 0.10 & 0.59 \\
\hline $\mathrm{ADF}$ intake, $\mathrm{kg} /$ day & 3.52 & 3.56 & 3.63 & 3.81 & 0.13 & 0.22 & 0.40 & 0.61 \\
\hline MPE, milk yield/DMI & 1.01 & 1.03 & 1.10 & 1.03 & 0.05 & 0.33 & 0.58 & 0.38 \\
\hline Fat yield, $\mathrm{kg} /$ day & 0.62 & 0.60 & 0.67 & 0.63 & 0.04 & 0.39 & 0.51 & 0.80 \\
\hline Protein yield, kg/day & 0.65 & 0.67 & 0.74 & 0.76 & 0.04 & 0.05 & 0.66 & 0.90 \\
\hline \multicolumn{9}{|l|}{ Milk composition, $\%$} \\
\hline fat & 3.32 & 3.13 & 3.11 & 2.94 & 0.18 & 0.30 & 0.35 & 0.95 \\
\hline protein & 3.48 & 3.52 & 3.40 & 3.55 & 0.05 & 0.62 & 0.12 & 0.33 \\
\hline lactose & 4.00 & 3.97 & 3.96 & 4.13 & 0.37 & 0.87 & 0.86 & 0.80 \\
\hline dry matter & 11.50 & 11.28 & 11.23 & 11.27 & 0.22 & 0.55 & 0.69 & 0.57 \\
\hline \multicolumn{9}{|l|}{ Nitrogen fractions } \\
\hline total $\mathrm{N}, \mathrm{g} / \mathrm{L}$ & 5.46 & 5.52 & 5.34 & 5.57 & 0.08 & 0.65 & 0.12 & 0.31 \\
\hline protein, $\mathrm{g} / \mathrm{L}$ & 4.92 & 4.95 & 4.76 & 4.98 & 0.09 & 0.49 & 0.22 & 0.32 \\
\hline casein, g/L & 3.68 & 3.81 & 3.69 & 3.70 & 0.07 & 0.50 & 0.36 & 0.41 \\
\hline whey $\mathrm{N}, \mathrm{g} / \mathrm{L}$ & 1.25 & 1.14 & 1.07 & 1.28 & 0.14 & 0.90 & 0.71 & 0.30 \\
\hline NPN, g/L & 0.54 & 0.57 & 0.58 & 0.58 & 0.04 & 0.50 & 0.62 & 0.71 \\
\hline protein $\mathrm{N} /$ total N, \% & 90.35 & 90.18 & 89.28 & 89.82 & 0.88 & 0.45 & 0.84 & 0.70 \\
\hline casein N/total N, \% & 67.81 & 68.92 & 69.24 & 67.16 & 1.70 & 0.93 & 0.78 & 0.39 \\
\hline
\end{tabular}

FCM - 4\% fat corrected milk, RUP intake - rumen undegradable protein intake, SE - standard error of the least square means

a,b,c means with different superscript letter are significantly different $(\mathrm{P}<0.05)$ 
TABLE 3

Physiologic response of the cows to sprinkler+fan (SF) and fish meal (FM)

\begin{tabular}{|c|c|c|c|c|c|c|c|c|c|}
\hline \multicolumn{2}{|l|}{ Sprinkler+Fan } & \multicolumn{2}{|c|}{ No } & \multicolumn{2}{|c|}{ Yes } & & \multicolumn{3}{|c|}{ Effects $(\mathrm{P}<)$} \\
\hline Fish Meal & Time & No & Yes & No & Yes & & SF & FM & $\mathrm{SF} \times \mathrm{FM}$ \\
\hline \multirow{3}{*}{$\begin{array}{l}\text { Rectal temperature, } \\
{ }^{\circ} \mathrm{C}\end{array}$} & 11.30 & 38.8 & 38.8 & 38.4 & 38.6 & 0.15 & 0.15 & 0.60 & 0.50 \\
\hline & 13.30 & $39.2^{\mathrm{a}}$ & $38.8^{\mathrm{b}}$ & $38.5^{\mathrm{c}}$ & $38.4^{\mathrm{c}}$ & 0.04 & 0.01 & 0.01 & 0.03 \\
\hline & 15.30 & $39.2^{\mathrm{a}}$ & $38.9^{\mathrm{a}}$ & $38.3^{b}$ & $38.1^{\mathrm{b}}$ & 0.12 & 0.01 & 0.10 & 0.84 \\
\hline \multirow{3}{*}{ Skin temperature, ${ }^{\circ} \mathrm{C}$} & 11.30 & $35.5^{\mathrm{a}}$ & $35.5^{\mathrm{a}}$ & $33.5^{\mathrm{b}}$ & $33.6^{\mathrm{b}}$ & 0.46 & 0.01 & 1.00 & 0.88 \\
\hline & 13.30 & $35.1^{\mathrm{a}}$ & $34.6^{\mathrm{ab}}$ & $34.2^{\mathrm{ab}}$ & $33.7^{\mathrm{b}}$ & 0.28 & 0.02 & 0.13 & 0.93 \\
\hline & 15.30 & $34.6^{\mathrm{a}}$ & $34.8^{\mathrm{a}}$ & $33.3^{\mathrm{b}}$ & $33.2^{\mathrm{b}}$ & 0.36 & 0.01 & 1.00 & 0.64 \\
\hline \multirow{3}{*}{$\begin{array}{l}\text { Respiration rate, } \\
\text { number/min }\end{array}$} & 11.30 & $82.0^{\mathrm{a}}$ & $76.0^{\mathrm{a}}$ & $51.5^{\mathrm{b}}$ & $46.5^{\mathrm{b}}$ & 5.00 & 0.01 & 0.31 & 0.92 \\
\hline & 13.30 & $87.5^{\mathrm{a}}$ & $83.0^{\mathrm{a}}$ & $60.0^{\mathrm{b}}$ & $53.5^{\mathrm{b}}$ & 2.78 & 0.01 & 0.10 & 0.73 \\
\hline & 15.30 & $89.0^{\mathrm{a}}$ & $82.5^{\mathrm{a}}$ & $48.5^{\mathrm{b}}$ & $48.5^{\mathrm{b}}$ & 3.61 & 0.01 & 0.40 & 0.40 \\
\hline \multirow{3}{*}{$\begin{array}{l}\text { Heart rate, } \\
\text { number/min }\end{array}$} & 11.30 & 74.0 & 76.5 & 71.5 & 71.8 & 3.23 & 0.31 & 0.69 & 0.74 \\
\hline & 13.30 & 75.5 & 80.5 & 77.0 & 76.5 & 4.10 & 0.77 & 0.60 & 0.53 \\
\hline & 15.30 & 76.5 & 79.0 & 73.0 & 76.5 & 2.74 & 0.32 & 0.32 & 0.86 \\
\hline
\end{tabular}

SE - standard error of the least square means

a,b,c means with different superscript letter are significantly different $(\mathrm{P}<0.05)$

TABLE 4

The effects of sprinkler+fan (SF) and protected fat (PF) on milk yield, DM and nutrient intakes, and milk composition

\begin{tabular}{|c|c|c|c|c|c|c|c|c|}
\hline \multirow{2}{*}{$\begin{array}{l}\text { Sprinkler+Fan } \\
\text { Protected Fat }\end{array}$} & \multicolumn{2}{|c|}{ No } & \multicolumn{2}{|c|}{ Yes } & \multirow{2}{*}{$\mathrm{SE}$} & \multicolumn{3}{|c|}{ Effects $(\mathrm{P}<)$} \\
\hline & No & Yes & No & Yes & & SF & PF & $\mathrm{SF} \times \mathrm{FM}$ \\
\hline Milk yield, kg/day & 18.73 & 20.20 & 20.15 & 21.23 & 0.78 & 0.17 & 0.15 & 0.81 \\
\hline FCM, kg/day & 18.03 & 20.70 & 18.60 & 20.82 & 0.88 & 0.70 & 0.03 & 0.81 \\
\hline DMI, kg/day & 19.70 & 19.65 & 19.54 & 20.44 & 0.41 & 0.48 & 0.34 & 0.30 \\
\hline RUP intake, $\mathrm{kg} /$ day & 1.25 & 1.22 & 1.24 & 1.29 & 0.03 & 0.39 & 0.73 & 0.23 \\
\hline ME intake, Mcal/day & 49.64 & 49.52 & 49.24 & 51.50 & 1.04 & 0.48 & 0.34 & 0.29 \\
\hline $\mathrm{CP}$ intake, $\mathrm{kg} /$ day & 3.56 & 3.59 & 3.53 & 3.74 & 0.08 & 0.47 & 0.16 & 0.30 \\
\hline NDF intake, $\mathrm{kg} /$ day & $5.51^{\mathrm{b}}$ & $6.29^{\mathrm{a}}$ & $5.46^{\mathrm{b}}$ & $6.55^{\mathrm{a}}$ & 0.12 & 0.42 & 0.01 & 0.26 \\
\hline ADF intake, $\mathrm{kg} /$ day & $3.62^{\mathrm{b}}$ & $3.91^{\mathrm{a}}$ & $3.59^{\mathrm{b}}$ & $4.06^{\mathrm{a}}$ & 0.08 & 0.44 & 0.01 & 0.28 \\
\hline MPE, milk yield/DMI & 0.96 & 1.03 & 1.04 & 1.04 & 0.03 & 0.15 & 0.20 & 0.25 \\
\hline Fat yield, kg/day & 0.70 & 0.84 & 0.71 & 0.82 & 0.04 & 0.87 & 0.03 & 0.83 \\
\hline Protein yield, kg/day & 0.70 & 0.71 & 0.72 & 0.77 & 0.02 & 0.12 & 0.25 & 0.39 \\
\hline \multicolumn{9}{|l|}{ Milk composition, \% } \\
\hline fat & $3.81^{\mathrm{ab}}$ & $4.24^{\mathrm{a}}$ & $3.52^{\mathrm{b}}$ & $3.92^{\mathrm{ab}}$ & 0.19 & 0.16 & 0.07 & 0.94 \\
\hline protein & 3.78 & 3.55 & 3.66 & 3.68 & 0.11 & 0.95 & 0.42 & 0.31 \\
\hline lactose & 3.57 & 3.55 & 4.50 & 3.34 & 0.33 & 0.32 & 0.13 & 0.14 \\
\hline dry matter & 11.90 & 12.09 & 12.37 & 11.71 & 0.26 & 0.87 & 0.41 & 0.15 \\
\hline
\end{tabular}


TABLE 4 continued

\begin{tabular}{|c|c|c|c|c|c|c|c|c|}
\hline \multirow{2}{*}{$\begin{array}{l}\text { Sprinkler+Fan } \\
\text { Protected Fat }\end{array}$} & \multicolumn{2}{|c|}{ No } & \multicolumn{2}{|c|}{ Yes } & \multirow{2}{*}{ SE } & \multicolumn{3}{|c|}{ Effects $(\mathrm{P}<)$} \\
\hline & No & Yes & No & Yes & & SF & $\mathrm{PF}$ & $\mathrm{SF} \times \mathrm{FM}$ \\
\hline \multicolumn{9}{|l|}{ Nitrogen fractions } \\
\hline total $\mathrm{N}, \mathrm{g} / \mathrm{L}$ & 5.92 & 5.57 & 5.73 & 5.77 & 0.18 & 0.97 & 0.41 & 0.31 \\
\hline protein, $g / L$ & 5.40 & 5.03 & 5.16 & 5.22 & 0.21 & 0.92 & 0.49 & 0.35 \\
\hline casein, g/L & 3.90 & 3.88 & 3.92 & 3.88 & 0.07 & 0.93 & 0.68 & 0.93 \\
\hline whey $\mathrm{N}, \mathrm{g} / \mathrm{L}$ & 1.50 & 1.15 & 1.25 & 1.35 & 0.16 & 0.87 & 0.46 & 0.21 \\
\hline NPN, g/L & 0.52 & 0.54 & 0.58 & 0.56 & 0.05 & 0.53 & 1.00 & 0.70 \\
\hline protein $\mathrm{N} /$ total N, \% & 91.44 & 90.58 & 90.03 & 90.69 & 1.15 & 0.59 & 0.93 & 0.53 \\
\hline casein N/total N, \% & 65.99 & 69.67 & 69.09 & 67.46 & 1.17 & 0.71 & 0.41 & 0.06 \\
\hline
\end{tabular}

FCM - 4\% fat corrected milk, RUP - rumen undegradable protein, SE - standard error of the least square means, ${ }^{\mathrm{a}, \mathrm{b}, \mathrm{c}}$ means with different superscript letter are significantly different $(\mathrm{P}<0.05)$

TABLE 5

Physiological response of the cows to sprinkler+fan (SF) and protected fat (PF)

\begin{tabular}{|c|c|c|c|c|c|c|c|c|c|}
\hline \multicolumn{2}{|l|}{ Sprinkler+Fan (SF) } & \multicolumn{2}{|c|}{ No } & \multicolumn{2}{|c|}{ Yes } & \multirow{2}{*}{ SE } & \multicolumn{3}{|c|}{ Effects $(\mathrm{P}<)$} \\
\hline Protected fat (PF) & Time & No & Yes & No & Yes & & SF & $\mathrm{PF}$ & $\mathrm{SF} \times \mathrm{PF}$ \\
\hline \multirow{3}{*}{$\begin{array}{l}\text { Rectal } \\
\text { temperature, }{ }^{\circ} \mathrm{C}\end{array}$} & 11.30 & $39.0^{\mathrm{a}}$ & $39.1^{\mathrm{a}}$ & $38.5^{\mathrm{b}}$ & $38.5^{\mathrm{b}}$ & 0.03 & 0.01 & 0.37 & 0.37 \\
\hline & 13.30 & $39.4^{\mathrm{a}}$ & $39.3^{\mathrm{b}}$ & $38.4^{\mathrm{d}}$ & $38.6^{\mathrm{c}}$ & 0.03 & 0.01 & 0.32 & 0.01 \\
\hline & 15.30 & $39.5^{\mathrm{a}}$ & $39.0^{\mathrm{ab}}$ & $38.3^{\mathrm{c}}$ & $38.4^{\mathrm{bc}}$ & 0.19 & 0.01 & 0.34 & 0.19 \\
\hline \multirow{3}{*}{$\begin{array}{l}\text { Skin } \\
\text { temperature, }{ }^{\circ} \mathrm{C}\end{array}$} & 11.30 & $36.5^{\mathrm{a}}$ & $35.8^{\mathrm{a}}$ & $32.6^{\mathrm{b}}$ & $32.5^{b}$ & 0.51 & 0.01 & 0.47 & 0.66 \\
\hline & 13.30 & $35.6^{\mathrm{a}}$ & $35.2^{\mathrm{ab}}$ & $33.7^{\mathrm{ab}}$ & $33.6^{\mathrm{b}}$ & 0.54 & 0.02 & 0.62 & 0.81 \\
\hline & 15.30 & $34.7^{\mathrm{ab}}$ & $35.1^{\mathrm{a}}$ & $33.8^{\mathrm{ab}}$ & $33.0^{\mathrm{b}}$ & 0.51 & 0.02 & 0.71 & 0.28 \\
\hline \multirow{3}{*}{$\begin{array}{l}\text { Respiration rate, } \\
\text { number/min }\end{array}$} & 11.30 & $82.5^{\mathrm{a}}$ & $85.0^{\mathrm{a}}$ & $60.0^{\mathrm{b}}$ & $63.5^{\mathrm{ab}}$ & 7.72 & 0.03 & 0.71 & 0.95 \\
\hline & 13.30 & $90.0^{\mathrm{a}}$ & $84.0^{\mathrm{a}}$ & $56.5^{\mathrm{b}}$ & $59.0^{\mathrm{b}}$ & 4.27 & 0.01 & 0.70 & 0.36 \\
\hline & 15.30 & $93.3^{\mathrm{a}}$ & $85.3^{\mathrm{a}}$ & $59.0^{\mathrm{b}}$ & $59.0^{\mathrm{b}}$ & 4.11 & 0.01 & 0.40 & 0.40 \\
\hline \multirow{3}{*}{$\begin{array}{l}\text { Heart rate, } \\
\text { number/min }\end{array}$} & 11.30 & 77.0 & 84.3 & 78.0 & 75.5 & 3.34 & 0.29 & 0.50 & 0.20 \\
\hline & 13.30 & 80.0 & 81.5 & 78.5 & 81.5 & 3.76 & 0.85 & 0.57 & 0.85 \\
\hline & 15.30 & 80.5 & 83.0 & 82.0 & 71.0 & 4.06 & 0.24 & 0.34 & 0.15 \\
\hline
\end{tabular}

SE - standard error of the least square means

a,b,c means with different superscript letter are significantly different $(\mathrm{P}<0.05)$

fractions of milk. However, calculated rumen undegradable protein intake (RUPI; $\mathrm{P}=0.06)$, NDF intake (NDFI; $\mathrm{P}=0.10)$ and milk protein content $(\mathrm{P}=0.12)$ of the cows fed with the diet containing FM were tended to be higher than those of the cows fed diet without FM. FM decreased rectal temperature at 13.30 $(\mathrm{P}<0.01)$ and also tended to decrease rectal temperature at $15.30(\mathrm{P}=0.10)$ and respiration rate at $13.30(\mathrm{P}=0.10$; Table 3$)$. During the experiment no significant interaction $(\mathrm{P}>0.05)$ between cooling and protein quality was observed for any 
parameters examined, except rectal temperature, which was decreased at 13.30 $(\mathrm{P}<0.05)$ by $\mathrm{FM}$ in the non-cooled cows but not in the cooled cows.

$\mathrm{PF}$ increased FCM and fat yield $(\mathrm{P}<0.05)$ and also tended to increase $(\mathrm{P}=0.07)$ milk fat content independently from SF application (Table 4). Rectal, skin temperature, respiration rate and heart rate were not affected $(\mathrm{P}>0.05$; Table 5) by $\mathrm{PF}$ and $\mathrm{SF} \times \mathrm{PF}$ interaction, except rectal temperature at $13.30(\mathrm{P}<0.01)$. Rectal temperature was lower for the non-cooled cows fed with PF compared to the cows fed the diet without PF. This effect was reversed for the cooled cow and rectal temperature was higher for the cows fed the diet with PF than those fed the diet without PF.

\section{DISCUSSION}

The results obtained in the present study showed that providing sprinkler and fan system as a cooling agent could have the potential to improve milk yield under high temperature condition. The results also showed that the cooled cows had also higher milk protein yield in the FM meal study and tended to have higher milk protein yield in the PF study due to slightly higher milk yield than the noncooled cows. The positive lactational response of the cows to evaporative cooling during hot summer months were obtained in the previous studies (e.g., Igono et al., 1987). Similarly, Flamenbaum et al. (1995) observed $1.9 \mathrm{~kg} \mathrm{~d}^{-1}$ milk yield increase by cooling, although it was not significant.

The increases in milk yields of the cooled cows observed in the present study could be associated with their physiological responses to the SF. SF application decreased rectal temperature (except at 11.30), skin temperature and respiration rate. Depending on these physiological responses, the cooled cows maintained rectal temperature below $38.6^{\circ} \mathrm{C}$, skin temperature below $34.2^{\circ} \mathrm{C}$ and respiration rate below 64 breaths $\min ^{-1}$ in the both experiments. The hourly values of THI calculated during the experiment (Figure 1) showed that our animals experienced mild stress from 07.00 to 10.00 and from 17.00 to 23.00 and moderate stress from 10.00 to 17.00 . The hourly average values of THI were ranged between 69 and 80 throughout a day during the entire experimental period. Armstrong (1994) classified thermal stress according to THI; values from 72-79 is stated as mild stress, values from 80 to 89 is medium stress, and the values over 90 is severe stress. On the other hand, our findings with respect to milk yield and physiological responses supported the results of Berman et al. (1985). They reported that ambient temperature above $27^{\circ} \mathrm{C}$ and rectal temperature above $39^{\circ} \mathrm{C}$ caused a reduction of milk yield. In our experiments, the environmental temperature from 08.00 to 
18.00 and rectal temperature of the noncooled cow during the experimental period were higher than the threshold values reported above by Berman et al. (1985).

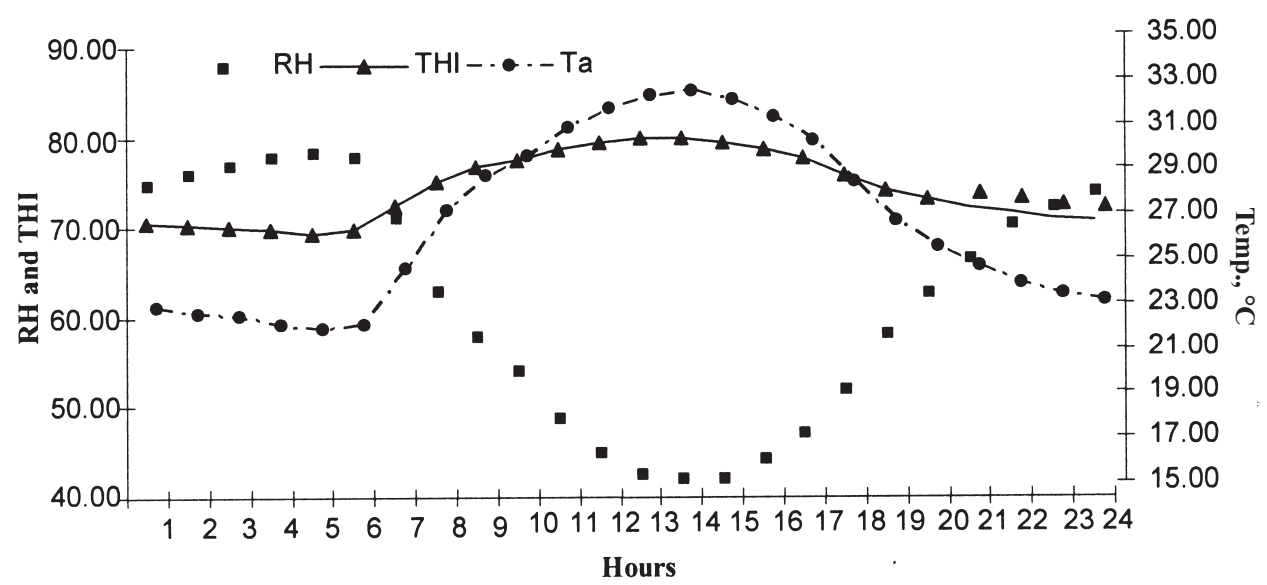

Figure 1. Average diurnal changes of relative humidity $(\mathrm{RH}, \%)$, ambient temperature $\left(\mathrm{Ta},{ }^{\circ} \mathrm{C}\right)$ and temperature-humidity index (THI) during entire experiment

The results also showed that the cows marginally responded to SF with respect to milk yield and milk composition. This could be attributed to their relatively low milk yield (Armstrong, 1994). Additionally, it was revealed that increases in milk yield with evaporative cooling were associated with an increase in DMI besides a decrease in rectal temperature and respiration rate (Taylor et al., 1991; Armstrong, 1994). SF decreased rectal temperature and respiration rate in the present studies, but DMI, CPI, MEI were not improved by SF. Depending on the decrease in rectal temperature and respiration rate by SF, the reduced maintenance cost (Huber et al., 1994) of the cooled cows could be responsible from the limited improvement in milk yield. Similarly, DMI and nutrient supply for cooled and non-cooled cows may be, therefore, related to the ability of the cows suffering mild heat stress to compensate the decrease in feed intake by consuming more feed during cool time of the day. The present literature (e.g., Tarazon-Herrera et al., 1999) also revealed that milk fat depression of heat stressed cows due to sorting of concentrate and forage in the feed bunk may be avoided by assigning evaporative cooling. In the present studies, SF had no significant effect on milk fat test. This finding supported the previous finding of Tarazon-Herrera et al. (1999) and it may also be attributed to TMR preventing a shift forage-to-concentrate ratio due to sorting by the cows, since lucerne hay having $1.5-2 \mathrm{~cm}$ particle size and concentrate were mixed well in the present study. 
FM was found to be no effects on milk yield, milk composition and nitrogen fractions of milk. However, calculated rumen undegradable protein intake, NDF intake and milk protein content of the cows fed with the diet containing FM were tended to be higher than those obtained from the diet without FM. The inclusion of FM to diets tended to increased RUPI and milk protein content, but did not improve milk yield and milk composition of the cows. No interaction between SF and FM was observed for the lactational performance. FM decreased rectal temperature at 13.30 and tended to decrease rectal temperature at 15.30 and respiration rate at 13.30. Decreases in rectal temperature and respiration rate could be attributed to improvement in nutrient utilization due to the balanced amino acid supply to tissues. Furthermore, highly degradable protein sources such as soyabean meal may increase heat load to animal body due to inefficient use of excess ammonia nitrogen in the rumen and the high energy cost for the conversion of the excess ammonia into urea at liver (Huber et al., 1994). Hence the decreasing such a heat load to animal may alleviate heat stress when the fish meal is used as rumen escape and high quality protein for dairy cows during heat stress (Taylor et al., 1991).

FM did not improve milk yield and milk composition markedly in the present study. However, there was only a slight increase in milk protein content (3.44 vs $3.54 \%$ ) by FM. The results reported in the literature with regard to the effect of FM on milk yield were inconsistent. Some studies (e.g., Chen et al., 1993) showed that FM improved milk yield due to supplying high amount of essential amino acids to the small intestine, but others (e.g., Santos et al., 1998) showed no positive effects. Furthermore, all diets used in the present studies were formulated with higher $\mathrm{CP}$ content than the requirements of the cows in mid lactation to alleviate the potential decrease in DMI during heat stress (Hassan and Roussel, 1975). However, Arieli et al. (2004) reported that there is no obvious reason to increase the dietary crude protein and rumen undegradable protein concentration under heat stress conditions. The limited and/or no improvement in milk yield and milk nitrogen fractions with FM in the present study might have been resulted from enough supply of essential amino acids by all diets.

The results obtained in the present study also showed no significant interaction between cooling and protein quality. However, Taylor et al. (1991) reported that the cooled cows fed on low degradable protein produced more milk than the noncooled cows on high degradable protein or than either the cooled or the non-cooled cows on high degradable protein when thermal stress was high. Similar trend was also reported by Chen et al. (1993). The relatively high protein content in the diets and enough rumen undegradable protein supply from all diets may have masked probable FM effect and protein sources $\times$ SF interaction on milk yield and DMI in the present study. 
The results obtained in the second study showed that PF increased FCM yield and fat yield. Rectal and skin temperatures, respiration and heart rates were not affected by PF. Supplemental fat generally increases milk yield under thermoneutral environment (Maiga and Schingoethe, 1997) or heat stressed condition (Chan et al., 1997; Drackley et al., 2003). However feeding fat in isocaloric diets increased milk yield in some (e.g., Vazquez-Anon et al., 1997), but not in all studies (e.g., Drackley et al., 2003). The diets used in the present study were isocaloric and the effect of fat was not depending on SF (no SF $\times$ PF interaction) for lactational performance. These findings are in agreement with the results of Knapp and Grummer (1991) and Chan et al. (1997) who reported that there was no interaction between evaporative cooling and dietary fat.

The higher FCM, slightly higher milk yield and milk fat test of the cows fed with PF in the present study may be a reflection of increasing energetic efficiency in the rumen due to reduction in methane production (Drackley et al., 2003) and by directing energy usage from fat deposition to milk production (Grum et al., 1996) by dietary protected fat. Furthermore, using dietary long chain fatty acids could be energetically more efficient than acetate for milk fat and body fat synthesis (Baldwin et al., 1980). Increase in milk fat percentage (Holter et al., 1993) or yield (Christensen et al., 1994) by dietary fat was also reported. Another contributing factor for high milk fat test for the PF diet is high ADF and NDF intakes of the cows fed PF. This high intake was resulted from the higher ADF and NDF content of PF diet due to high level of wheat bran than control diet ( $8.8 \%$ for control diet and $20.8 \%$ for PF diet). However VazquezAnon et al. (1997) reported that isocaloric high grain and high fat diets differing in NDF content had similar milk fat test and milk fat yield.

Low protein content of milk is often associated with supplemental fat in the diet of dairy cows (DePeters and Cant, 1992). However, there was no effect of PF on milk protein content in the present study. This result could be explained by the fat source, level and dietary protein level assigned in the present study. Calcium salt of long chain fatty acids used in the study has no effect on rumen microorganism (Schauff et al., 1992) and the level of total fat in the diet are within the tolerable level for rumen microorganism (Palmquist and Jenkins, 1980). Furthermore, there is no limitation in respect to amino acid supply to small intestine, since the diets used in the study were formulated with relatively high crude protein as reported in the FM study.

\section{CONCLUSIONS}

The results obtained in the present studies indicate that SF decreased rectal and skin temperatures and respiration rate as indices of the alleviation of heat stress. Accordingly, supplying sprinkler+fan (SF) improved milk yield 2.21 and $1.22 \mathrm{~kg}$ 
daily in the fish meal (FM) and protected fat (PF) studies, respectively. FM had no positive effect on milk yield in cooled or non-cooled cows, but tended to increase milk protein (3.44 vs 3.54\%) independently from SF application. Additionally, PF increased FCM, milk fat yield and tended to increase percentage independently from SF application.

The results of the both trials suggest that management manipulation such as applying sprinklers plus fan can improve milk yield better than nutritional manipulation using either FM or PF. The results also suggest that PF is more beneficial than FM under heat stress condition when the dietary protein level is high.

\section{REFERENCES}

AOAC, 1998. Official Methods of Analysis, Association of Official Analytical Chemists. $16^{\text {th }}$ Edition. Washington, DC

Arieli A., Adin G., Bruckental I., 2004. The effect of protein intake on performance of cows in hot environmental temperatures. J. Dairy Sci. 87, 620-629

Armstrong D.V., 1993. Environmental modification to reduce heat stress. Western Large Herd Management Conference. Las Vegas, Nevada, pp.1-8

Armstrong D.V., 1994. Heat stress interaction with shade and cooling. J. Dairy Sci. 77, 2044-2050

Baldwin R.L., Smith N.E., Taylor J., Sharp M., 1980. Manipulating metabolic parameters to improve growth rate and milk secretion. J. Anim. Sci. 51, 1416-1428

Berman A., Foldman Y., Kaim M., Mamem M., Herz Z., Wolfenson D., Arieli A., Graber Y., 1985. Upper critical temperatures and forced ventilation effects for high yielding dairy cows in a subtropical climate. J. Dairy Sci. 68, 1488-1495

Chan S.C., Huber J.T., Chen K.H., Simas J.M., Wu Z., 1997. Effects of ruminally inert fat and evaporative cooling on dairy cows in hot environmental temperature. J. Dairy Sci. 80, 11721178

Chen K.H., Huber J.T., Theurer C.B., Armstrong D.V., Vanderley R.C., Simas J.M., Chan S.C., Sullivan J.L., 1993. Effect of protein quality and evaporative cooling on lactational performance of Holstein cows in hot weather. J. Dairy Sci. 76, 819-825

Christensen R.A., Cameron M.R., Clark J.H., Drackley J.K., Lynch J.M., Barbano D.M., 1994. Effects of amount of protein and ruminally protected amino acids in the diet of dairy cows fed supplemental fat. J. Dairy Sci. 77, 1618-1629

DePeters J.E., Cant J.P., 1992. Nutritional factors influencing the nitrogen composition of bovine milk. J. Dairy Sci. 75, 2043-2070

Drackley J.K., Cicela T.M., LaCount D.W., 2003. Response of primaparous and multiparous Holstein cows to additional energy from fat or concentrate during summer. J. Dairy Sci. 86, 1306-1314

Flamenbaum I., Wolfenson D., Kunz P.L., Maman M., Berman A., 1995. Interaction between body condition at calving and cooling of dairy cows during lactation in summer. J. Dairy Sci. 78, 2221-2229

Gebremedhin K.G., Wu B., 2002. Simulation of sensible and latent heat losses from wet-skin surface and fur layer. J. Therm. Biol. 27, 291-297

Grum D.E., Drackley J.K., Hansen L.R., Cremin Jr J. D., 1996. Production, digestion, and hepatic lipid metabolism of dairy cows fed increased energy from fat or concentrate. J. Dairy Sci. 79, 1836-1849 
Hassan A., Roussel J.D., 1975. Effect of protein concentration in the diet on blood composition and productivity of lactating Holstein cows under thermal stress. J. Agr. Sci. 85, 409-415

Higginbotham G.E., Huber J.T., Wallentine W.V., Johnson N.P., Andrus D., 1989. Influence of protein percent and degradability on performance of lactating cows during moderate temperature. $\mathrm{J}$. Dairy Sci. 72, 1818-1823

Holter J.B., Hayes H.H., Kierstead N., Whitehouse J., 1993. Protein fat bypass supplement for lactating dairy cow. J. Dairy Sci. 76, 1342-1352

Huber J.T., Higginbotham G., Gomez-Alarcon R.A., Taylor R.B., Chen K.H., Wu Z., 1994. Heat stress interaction with protein, supplemental fat and fungal cultures. J. Dairy Sci. 77, 20802090

Igono M.O., Johnson H.D., Stevens B.J., Krause G.F., Shanklin M.D., 1987. Physiological, productive, and economic benefits of shade, spray, and fan system vs shade for Holstein cows during summer heat. J. Dairy Sci. 70, 1069-1079

Knapp D.M., Grummer R.R., 1991. Response of lactating dairy cows to fat supplementation during heat stress. J. Dairy Sci. 74, 2573-2579

Lefcourt A.M., Schmidtmann E.T., 1989. Body temperature of dry cows on pasture: enviromental and behavioral effects. J. Dairy Sci. 72, 3040-3049

Madison-Anderson R.J., Schingothe D.J., Brouk M. J., Baer R.J., Lenthsch M.R., 1997. Response of lactating cows to supplemental unsaturated fat and niacin. J. Dairy Sci. 80, 1329-1338

Maiga H.A., Schingoethe D.J., 1997. Optimizing the utilization of animal fat and ruminal bypass proteins in the diets of lactating dairy cows. J. Dairy Sci. 80, 343-352

NRC, 2001. Nutrient Requirements of Dairy Cattle. $7^{\text {th }}$ revised Edition. National Academy Press. Washington, DC

Overton T.R., Emmert L.S., Clark J.H., 1998. Effects of sources of carbohydrate and protein and rumen-protected methionine on performance of cows. J. Dairy Sci. 8, 221-228

Palmquist D.L., Jenkins T.C., 1980. Fat in lactation ration: Review. J. Dairy Sci. 63, 1-14

Santos F.A.P., Santos J.E.P., Theurer C.B., Huber J.T., 1998. Effects of rumen-undegradable protein on dairy cow performance: A 12 year literature review. J. Dairy Sci . 81, 3182-3213

SAS, 1985. Statistical Analyses System, SAS User's Guide: Statistics. SAS Institute, Inc., Carry, $\mathrm{NC}$

Schauff D.J., Clark J.H., Drackley J.K., 1992. Effects of feeding lactating dairy cows diets containing extruded soybeans and calcium salts of long-chain fatty acids. J. Dairy Sci. 75, 3003-3019

Tarazon-Herrera M., Huber J.T., Santos J., Mena H., Unzo L., Nussio C., 1999. Effects of bovine somatotropin and evaporative cooling plus shade on lactation performance of cows during summer heat stress. J. Dairy Sci. 82, 2352-2357

Taylor R.B., Huber J.T., Gomez-Alarcon R.A., Wiersma F., Pang X., 1991. Influence of protein degradability and evaporative cooling on performance of dairy cows during hot environmental temperature. J. Dairy Sci. 74, 243-249

Van Soest P.J., Robertson J.B., Lewis B.A., 1991. Methods for dietary fiber, neutral detergent fiber, and nonstarch polsaccharides in relation to animal nutrition. J.Dairy Sci. 74, 3583-3597

Vazquez-Anon M., Bertics S.J., Grummer R.R., 1997. The effect of dietary energy source during mid to late lactation on liver triglyceride and lactation performance of dairy cows. J. Dairy Sci. $80,2504-2512$

White T.W., Bunting L.D., Sticker L.S., Hembry F.G., Saxton A.M., 1992. Influence of fish meal and supplemental fat on performance of finishing steers exposed to moderate or high ambient temperatures. J. Anim. Sci. 70, 3286-3292 


\section{STRESZCZENIE}

\section{Wpływ zraszania i wentylacji oraz dodatku mączki rybnej lub tłuszczu do diety na wydajność i skład mleka krów w połowie laktacji w okresie letnim}

Przeprowadzono dwa doświadczenia, których celem była ocena 1. efektywności zraszania+wentylowania (SF) oraz dodatku mączki rybnej (FM) do dawki oraz 2. dodatku thuszczu chronionego (PF) na złagodzenie stresu cieplnego u krów mlecznych w połowie laktacji. Badania przeprowadzono w $2 \times 2$ układzie czynnikowym i $4 \times 4$ układzie kwadratu łacińskiego. W pierwszym doświadczeniu skarmiano dawki: 1. bez SF i bez FM, 2. bez SF i z dodatkiem 3,67\% FM w s.m. dawki, 3. SF i bez FM, 4. SF i 3,67\% FM. W drugim doświadczeniu układ był następujący: 1. bez SF i bez PF, 2. bez SF i dodatek 2,54\% PF w s.m. dawki, 3. SF i bez PF, 4. SF i dodatek 2,54\% $\mathrm{PF}$. Krowy otrzymywały izoenergetyczne i izoazotowe pasze TMR, zawierające 2,52 Mcal/EM/ kg s.m. i 180 g białka og./kg s.m. Krowy poddawane był łagodnemu stresowi od 7,00 do 10,00 i od 7,00 do 23,00 i umiarkowanemu stresowi od 17,00 do 23,00 każdego dnia, przez cały okres doświadczalny.

Stosowanie SF obniżyło $(\mathrm{P}<0,05)$ temperaturę mierzoną w odbytnicy i temperaturę skóry, oraz częstotliwość oddechów, a także poprawiło wydajność mleka o 2,21 kg w pierwszym ( $\mathrm{P}<0,07$; $\left.19,24 \mathrm{vs} 21,45 \mathrm{~kg} \cdot \mathrm{d}^{-1}\right)$ i o $1,22 \mathrm{~kg} \mathrm{w}$ drugim doświadczeniu $\left(\mathrm{P}=0,15 ; 19,47 \mathrm{vs} 20,69 \mathrm{~kg} \cdot \mathrm{d}^{-1}\right)$. Dodatek FM nie miał wpływu na wydajność mleka, tak u ochładzanych jak i nie ochładzanych krów, lecz wystapiła tendencja do zwiększenia $(\mathrm{P}=0,12)$ zawartość białka w mleku, niezależnie od sposobu postępowania $\mathrm{z}$ krowami. Dodatek PF spowodował zwiększenie wydajności FCM i thuszczu $(\mathrm{P}<0,05)$ oraz wystapiła tendencja do zwiększenia $(\mathrm{P}=0,07)$ zawartości tłuszczu, niezależnie od sposobu postępowania z krowami.

Wyniki obydwóch doświadczeń wskazują, że zastosowanie zraszania i wentylowania może wpłynąć na poprawą wydajności mleka w większym stopniu niż dodatek FM i PF. Otrzymane wyniki sugerują także, że dodatek PF może być skuteczniejszy niż FM w warunkach stresu cieplnego przy wysokim poziomie białka w dawce. 